\title{
Seeing is Believing.
}

\section{Anthropological Visions of Culture}

\author{
KEY WORDS \\ visual anthropology, \\ visual turn, culture, \\ history of image, \\ de-visualization \\ discourse
}

\begin{abstract}
Drozdowicz Jarema, Seeing is Believing. Anthropological Visions of Culture [Zobaczyć znaczy uwierzyć. Antropologiczne spojrzenia na kulturę]. Kultura Społeczeństwo - Edukacja nr 2 (4) 2013, Poznań 2013, pp.9-21, Adam Mickiewicz University Press. ISBN 978-83-232-2708-3. ISSN 2300-0422

The main argument of the article tends towards the assumption that the visual sphere of culture is one of the most significant features of human agency and it is closely connected to the process of constructing particular worldviews. The scientific discourse that follows the issue of visuality has therefore a long history of transitions and paradigm shifts, just like the cultural discourse in general. Cultural anthropology developed with the passing time also its own way of seeing things, especially when it comes to the conceptualization if cultural otherness. Visual anthropology, understood as an independent anthropological field of study, gained with time much recognition amongst other social sciences, being part of a much broader visual turn in the social sciences. What is significant the contemporary image discourse shifts its momentum towards the "native's point of view", i.e. it recaptures the reality in terms of subjective and culturally conditioned ways of percepting the world.
\end{abstract}

We may agree with a fair share of certainty, that as long anthropology is lasting the necessity of „seeing” the cultural „Other” was a constant companion of all ethnographic endeavors. Starting from the beginning of anthropological independence as a discipline looking upon other people from the ethnographer's stand point became an important instrument of cognition in its toolbox. Often useful, but sometimes by many also mistrusted, anthropological visions of culture contributed slowly to the building of a much broader world vision; a world beyond the narrow borders of ethnocentric European and Western dogmas. We became aware of the cultural determinations of the world view provided by the eye, or at least of the fact that these limitations exist. It was also constructing the framework of 
our worldviews through visualizations of the cultural horizon we share, as well we attempt to implement it to others. Therefore, the visual aspect of anthropology is the foremost significant factor in understanding how anthropology is contributing to the emergence of a fragile grid of cultural relations, which make the foundations of socio-cultural praxis. Visualization of culture within the anthropological paradigm is also based upon the assumption, that culture is characterized by the category of difference and the visual aspect of that inner differentiation is the first to be pointed out in the situation of cultural contact.

The gaze is in this context simultaneously an act of speech. We give names to things and people in the very moment we see them. We give shape to what is culturally indifferent and put light in what is obscure. By exposing the picture of the Other to our eyes we develop a specific image by using anthropological knowledge as our symbolic camera. However, the anthropological lens are using harsh light, but a soft focus, to recall the book title by James Peacock (see: Peacock, 2004). Just like the basic rule of photography, the smaller the aperture the larger is the depth of field, anthropology is using its specific optics to gather the vast amount of forms of human cultures in order to get in focus its object in the broad context it is functioning on every day basis. No matter if we speak of exotic customs, rituals, clothes, art, the way people look or behave, our eyes are the most important tool in the recognition of otherness in the first place. As other senses follow, we slowly build up the picture of the whole - someone who does not share the culture of our own. The Other is taken into account either through its aesthetical similarity or the lack of it; through implementing our judgment of taste onto structures of values not necessarily covering those shared by ourselves. In that case the category of aesthetic difference is turning into a culturally conditioned axiology. Even more, these esthetic concepts are sometimes being translated into natural categories, that is the concept of race and racial differentiation of human populations. By combining nature and culture our visuality is ordering the Other into an ontology of the senses. The oppositions emerging from that process had been put for a long period of time into terms such as high culture and low culture, civilization and savagery or simply beauty and ugliness.

If we take classical anthropology and its origins as a product of the transitions in Western thought we may also trace back the complex process of visualization of ethnographic knowledge. This process took shape in the midst surrounding the birth of modernity, but it certainly didn't started in the modern age. Cultural curiosity inspiring the collecting of exotic artifacts, or delivering the Other to western societies through graphic representations, such as paintings or sketches, was present from the very moment Europeans had acknowledged the fact, that their own position is not in the center of the universe, but they are just one of many civilizations inhabiting the known world. For ancient Greeks, just like for example 
Herodotus, describing the societies of the Middle East and the Mediterranean was as much important as picturing Greek military victories over the Persians in the form of bas-reliefs. Ancient art wasn't regarded as dead representation of a living reality. Pictures were brought into life through the addition of a specific socio-cultural and political praxis (i.e. rituals) emphasizing Greek success as a moral and in consequence a cultural victory over the barbaric hordes. Thus the visual aspect of culture was in that case dependant on all other spheres of human cultural agency. It was a part of a vast spectrum of cultural actions, undertaken with to bring it closer to the viewer's experience of it. A pure and sterile image was virtually non-existent without the praxis, that had put it in motion. Ancient art had delivered people a needed relevance to the reality, that was surrounding them. In consequence, culture was back then visual in the strict sense of the term. It couldn't be deprived of its visual aspect by putting pictures into the framework of art understood as an abstract set of esthetical ideas and norms. Everything could be seen and looked at by adding our own life experience to the given image and immediately could be grasped by the viewer as reality itself. The distinction between what is real and what is depicted was drawn according not to the ideology behind the image (or the discourse as we would say nowadays), but through the things portrayed. Gods, heroes or other mythic figures represented through ancient art were part of every day life just as any other personas. Their influence on the way people make their choices, how they act and what they do was essential in comprehension of their world view.

As well Europe in the Middle Ages, although rejecting most of ancient aesthetic traditions, did not differ much in that matter. Religion became an instant key to all questions and was regarded as the only source of reality, including visual perception. Even the word of God had to be translated into pictures in order to bring it closer to the masses, when we take into account the low literacy in that time. Religious passion depictured in the church paintings did make people of that time believe, that the final judgment will be brought upon the wicked, sinners, savages, pagans or simply non-Christians. Their only sin was not being us, but the Lord's punishment for being different was certain. There could be only one God, one Church and one valid civilization - a Christian dominion fighting an eternal struggle with infidels. The cultural basis for this assumption was drawn from a single and unquestionable source - the Holy Bible, or to be more specific - the Church's interpretation of it. Historical events that followed (Protestant revolution for example) showed that even this source could be misleading. On the other hand, Catholic Church deprived of its former political power maintained its cultural influence in the next ages shaping the anthropological concept of man and culture in strictly religious terms. Of course the cultural discourse of the Middle Ages and the years after was not anthropological in the contemporary sense of the 
word. "Anthropos” as a general category was bounded by the context it was surrounded. This changed with the rise of Enlightenment and 19th century social and philosophical paradigm. The imagery of this time period directed the study of man into the field of universal cultural characteristics share by all man kind, not just particular cultures. The myth of a "noble savage" did spread across Western hemisphere and early researchers contributed to its ideological foundations through basic ethnographic study of the world's cultural diversity by assembling what was regarded as visually interesting. The set of carefully selected cultural items, like material tools or "primitive" art, did quickly fill the shelves in European museums with various exotic artifacts. Their esthetic value had been estimated through their similarity with Western counterparts. 19th century ethnography focused clearly on collecting evidence of the primary role of white man's culture among existing and past civilizations. The image of the Other was pushed into the field of distant historical events that had shaped the contemporary image of the human kind, i.e. Western civilization. „Our living ancestors” were pictured as quasi Neolithic communities, in some sort similar to the Europeans, but also full of savagery and violence. Victorian imaginarium of anthropology was rich in such vague comparisons. Early techniques of capturing the image through daguerreotypes or photography could hardly reflect the cultural reality on the basis of the image alone. Visual anthropology was still in the making in that time. Therefore the question we have to raise in this context is not just when anthropology became visual, but also who did contributed to that phenomena, how culture had been pictured through the years, and (last but not least) why visualization became a significant issue not just in anthropology itself, but also other academic domains.

The very moment anthropology opened its eyes as an independent discipline within humanities was also the moment the Western world had started to look at other cultures from the position of colonial dominance, power and usually also by application of direct or indirect violence. However, before Victorian anthropology and colonialism had begun to start their own ethnographic enterprises in Africa or India, the study of culture used specific visual methods and data as a tool for systematic recreation of the existing and past cultural diversity. Of course the limitations of early 19th century technology couldn't provide the picture how these objects were used by their owners through photographs, sound recordings or movies, but nevertheless the Museums in London, Paris or Vienna started to be filled with cultural objects from every corner of the world, making for the viewers much easier to see how the tribes and civilizations outside Europe changed through the ages until its present form. The Other had to be put in display in all its diversity for the bourgeoisie eye to make it more real, possible to grasp, and rationally explained. The historical aspect of the interpretation of these exhibitions is obvious in the light of the ideology of social evolutionism or early positivism. Both approaches 
were taking the idea, that cultural diversity seen in the museums cabinets has also a natural basis, for granted. Again, the aesthetic evaluation of so called primitive art, however also much appealing to the 19th century artists milieu, took over and rationalization of the category of cultural difference has been moved onto the field of natural sciences. The holistic approach of anthropology in its infancy affected the study of culture in terms of race, natural order and development. Western civilization was considered as the most advanced form of cultural achievement of Man. The picture of the Other had gained much in its contrast. Monochrome visions of culture became common and dominant. As George Stocking states, the industrial revolution had put a symbolic mark in what was back then (i.e. traditional societies) and what is now (the Victorian society in Britain for example) (Stocking Jr., 1987: 187). Cultural primitivism was exaggerated and over exposed through collections of curiosities - stone tools of Aborigines, Egyptian mummies, or African fetishes. On the other side, cultural development was measured in technology and science; London's Crystal Palace where these mummies and fetishes were displayed was a good example of it. It was a clear symbolic self-expression of Western civilizatory and technological domination through architecture and art.

As technological means allowed to grasp the picture of anthropological field of research through photography and later also movies, the visual aspect became slowly, but surely an integral part of the ethnographic description of the cultural universe. The visual paradigm, still bounded by the direct experience of an image, was slowly entering mass production and reproduction pushing it beyond its context of origin. Thus the image became independent and had gained much autonomy. Nevertheless, the best way to look at a early 19th century daguerreotypes was to see them in person. As this technique is based by putting the image on a silver plate it may also be taken as a specific Lacanian mirror of the viewer. Civilized Europeans looked at themselves also often through the image of the savage depicted. What they did see, was an astonishing. A striking resemblance was found in these images, which linked the Europeans with the societies outside Europe through a fragile thread of historical associations. The nature of the main difference between both parties involved was grounded in terms of temporal discrepancy on the level of cultural development and modernization. According to many, the „bon sauvagé" was a direct reflection of a unspecific Neolithic community of first unnamed Europeans living somewhere in the midst of a distant history. In the eyes of the Enlightenment philosophy followers, the "savage within" could be domesticated if only one would reject everything what was irrational, i.e. superstition, magic, religion etc. - that is related to the past. One had to be oriented towards a modernist future, where there was no place left for all of these peculiar artifacts of the primitive past. Science, also social anthropology, was regarded as a tool for this transition, as well its visual aspect was instrumentalized by the ideology of 
(forced) modernization. Obedience to this positivistic postulate was compulsory and modern visual technology could help to overcome all obstacles. The birth of visual ethnography is closely linked with the emergence of new media. It is conditioned by the means we are given by the very historical moment we live in. The socio-cultural context of various approaches towards the visual is as much important as the pictures produced by visual ethnographers themselves. Building of a significant and contextualized relation between the picture and the viewer might be a key factor in reconstructing the critical trajectories of emergence of visual anthropology and the basic modern visual paradigm in the study of culture.

The photographic journeys of Edward Sheriff Curtis in the American Wild West by the end of 19th century deliver a good example how the construction of the image of Native Americans was perceived not just by ethnographers, but also by Curtis's fellow Americans, entering modernity equipped with a set of technological and scientific lens, which could provide a sharper image and more focused reflection of reality. Curtis's photographs depict American Indians in what was seen as their natural habitat - the great plains of the Mid West, pueblos of the South West or the stony coastal beaches of Alaska scattered with totemic poles. In a kind of mythological narrative Curtis is telling the story of the Sioux or the Navajo in phrases consisting just from images - much emotional, appealing and truly romantic in their esthetical and ideological level of interpretation. This does not change the fact that his viewers expected these images to be real. They were made in the heart of the American nation in its making, showing the slowly agonizing native tribes and cultures making room for a new Western civilization. So did thought Curtis's clients, like J.P. Morgan, who financed most of his expeditions. Although not a professional anthropologist, the American photographer influenced strongly through his works experts on Native American culture like his co-worker and friend George Byrd Grinnell. Their fruitful cooperation had made it possible to popularize a specific image (or simply a myth) of the Indians among white Americans. On the other hand it had also made the foundation for wide spread interest in the indigenous cultures.

Curtis's work published in the years 1907-1930 as the twenty volumes titled „The North American Indian” became without shadow of a doubt a almost instantly a success. Through placing the images in a carefully described stories telling the life style of the Indians, Curtis managed to fill the image stills with life and simultaneously gain interest from his readers across the continent, as well from abroad. The image of the Other, embraced by many, was slowly settling in the Western world view as a given idea of Otherness. The exoticism applied towards that imagery was surely a necessary element for distinguishing between us and them. The picture had won more of its contrast. Strongly technological Western world had looked at the Other with a feeling of a lost innocence, nobility and pureness that 
we once had. Curtis photographs had reflected that belonging in a way, which is even today regarded as highly esthetical. His photographs are often found and reproduced nowadays in a form of popular posters, t-shirts or even tattoos. For Curtis himself the American Indian was thus an excellent example of specific processes, which tackled all other indigenous groups and contributed to the vanishing of their culture or sometimes physically the Indian groups themselves due to war, starvation or disease brought by the colonizers. Indians of the South West became against their will a symbolic recapitulation of the most violent side of !9th century American history and of the cultural contacts between natives and the whites.

Rising dominance of the occidental view was recaptured by the American photographer by putting the Indians into imaginary frames of traditional culture. For Curtis making pictures was somehow remaking history, or to be more specific his own view of a very particular past. A past, which had moved the indigenous discourse into the area of made up Wild West imagery and not facts. Anthropological picture taking has been quickly transgressed into fictional picture making. An interesting aspect of this approach is related to Curtis's own method of work. It is known, that every single evidence of modernization of the Indians was removed from the frame, and he was also known for a careful preparation of the photo set and making all Western artifacts (like clocks, tools or clothing) simply disappear. This kind of falsification of image might be however conceptualized in reference to the ideology behind it. His oddly understood perfectionism was at the same time a moral postulate. He and some of his contemporaries was convinced of the importance of rescuing the traditional Indian culture from vanishing. The Sioux or the Navajo were themselves a „vanishing race" and the urgency of capturing precious moments of their genuine indigenous existence was as much important as portraying those people's life in terms acceptable and driven from the early Western anthropological theories of human cultural universalism. As an effect of this, Curtis was reluctant to go into the specific of a particular example, instead making general conclusions on all American Indians and expressing the idea, that ,all native peoples were a homogenous culture" (Kennedy, 2001:4).

In the light of Curtis work the ethnographic image became at that time an object of a more or less obvious manipulation. Staging scenes by photographers and movie makers for a better look in front of camera required an intervention in the picture itself. Two, most known examples of manipulating the cultural reality, are related to movies by Louis Buñuel, „Land without bread” and Robert J. Flaherty's "Nanook of the North” and „Man of Aran”. The mentioned movies are early 20th century attempts to reflect not quite strict ethnographic data, but to provide a general look on local European cultures and their folklore in an age of a spreading modernity. We may argue of course, that neither Buñuel nor Flaherty were anthropologists in a strict sense of the word. But Buñuel, a surrealist filmmaker, 
and Flaherty a pioneer in film documentary, were using the same ethnographic language for their different causes. Buñuel portrayed a local village on the SpanishPortuguese border operating with shock, disgust and moral provocation. Flaherty on the other side, imitated anthropological fieldwork. His goal was to present the universal struggle between man and nature. The Inuit family of Nanook had to fight for its survival in the far north just like the Irish fisher family of the Aran Isles had to undergo the final battle with the sea to maintain its economic existence. Direct interference in the picture is in both cases visible in falsification of ethnographic data for the sake of an audience attracting narration.

Changing facts, arranging ceremonies and inserting objects from different cultural contexts became fashionable. It turned into carefully constructed modus operandi of visual anthropology in that time. Natural cultural situations and picturing every day life of people were transformed to a culturally acceptable aesthetics. Everything had to be just perfect for the Western eye. This affects also the work of Curtis, criticized for obvious image manipulation at both levels - taking the actual picture and post production. Removing modern material artifacts was for Curtis and people of the modern age necessary for recapturing the true nature of the Wild West, where civilization and tradition clashed. American Indians were never wild enough with their horses and plumes, Pygmies of Congo never archaic enough with their bows and stone axes, and the Trobriand Islanders never exotic enough with their ceremonial masks and pearl necklaces. This iconography of otherness was interpreted as a symbolic triumph of civilization over savagery; a visual domination taking place along military, political and economic conquest of nonWesterners. Colonialism has been extended in this manner into the visual sphere.

This problem, tackled by Edward Said in his book „Orientalism”, is even more emphasized in the analysis by James Clifford of Marcel Griaule's ethnographic praxis in Africa in the 1930's (Clifford, 1983). What is significant here, is that Griaule, a leading figure in French ethnology beside Michel Leiris, had developed a specific concept of fieldwork - ,a documentary system (governed by images of collection, observation, and interrogation) and a initiatory complex (where dialogical processes of education and exegesis come to the fore)". These two approaches were perceived by Griaule as complementary. The shift from collecting the images to understanding the meaning of it was a smooth transgression from the imperial gaze to intercultural dialogue. During his Dakar-Djibouti and Mali missions Griaule collected a large number of photographs, which are now gathered in Musee de L'Homme in Paris. These images were for him not just dead objects; a final product of the anthropological fieldwork put in a static exposition. They might be brought to life again by reconstruction of a cultural map of the human terrain. The cartographic metaphor is here accurate in the sense of Griaule's work as a aerial spotter before his ethnological career. In his case the colonial eye isn't that harsh as Said 
would like to see. It is the absolute gaze from above. The visual data and observation has in the French scholar's view much more potential to deliver an adequate information on African cultures as interviews done in the field, according to him an uncertain form of oral collaboration. Griaule points out the assumption, that the image brings the „edge needed to provoke, control, and verify confessional discourses". It delivers the clarity of cultural relations, and in the context of colonial French rule over a large part of Africa this works both ways. Griaule observes and photographs the Dogon, and, as he witnessed, the natives are following his every step with their eyes. Nevertheless, this mutual observation was far from equality. It was a drama of application of colonial power and forcing obedience. More a situation of George Orwell's experience as a colonial police officer killing the infamous elephant, than a Clifford Geertz's participation in a Balinese cock fight. Compulsive capturing of the images was for Griaule the first step in a controlled process of revealing culture's hidden secrets.

With the decline of the colonial system, the vanishing of its traditional object of interest (traditional societies), and the processes of globalization anthropology shifted from the study of particular cultures in their local environments to questions on culture of a more philosophical nature. So did its visual sub-discipline. Thus culture became an issue understood in terms of subjective experience of the people captured on photographs and film. The experiment undertaken by Sol Worth and John Adair in 1966 by handing out $16 \mathrm{~mm}$ cameras to the Navajo Indians previously teaching them to use this equipment, has shown an existing gap in what anthropologists see and what is perceived by their native interlocutors. The same issue is raised in ethnographic cinema of Jean Rouch or Tim Asch. However, the image of the Other today became blurred and dynamic. The more we want it to stay still in the frame the more it is unreachable. The desire to get it in order, to structurize the existing cultural phenomena by freezing the moment on tape and to digitalize the visual data isn't over yet. As we come to the question why anthropology is still attached to this wishful thinking we may ask ourselves if anthropology can be ever deprived of its eyes at all. Seeing is believing, as visual recapturing of foreign rituals and customs brings them closer into our own cultural home; makes the Other if not our close neighbor and friend, than at least someone who's way of living we acknowledge. The important difference between today and early visualizations of cultures by Edward Curtis, Bronisław Malinowski and later by Gregory Bateson and John Collier lies upon the ideology behind ethnographic images. As Jean Rouch mentions in one of the interviews visual anthropology shares an uncertain future, but it will survive as long the production of ethnographic imagery does not become purely technical and will maintain its link to reality. Symbols are meaningless without the practice which puts them in motion. The practice of anthropology is what anthropologists do 
as James Peacock says. The practice of the image is to be seen and the visions of culture delivered by anthropology perform still quite well despite their more or less obvious limitations.

Today visual anthropology (ethnography) is a well established sub-discipline with a wide range of interest areas and a rich cognitive toolbox. Visualizing ethnographic knowledge is regarded as an important and often necessary part of the enterprise even today by a large group of fieldworkers. This omni-presence of the „visual" in anthropology is certainly an effect of the past debates and polemics on the nature of the anthropological work and its object of study, but it is also the consequence of the anthropological practice itself. The act of cognition is always linked with the senses. Understanding how the cultural „Other” thinks, acts and feels involves the sensory machinery we all posses and allows it to establish a close relation to what is out there by seeing, smelling, touching and hearing. Of course these senses may function both ways; they shape our image of reality through delivering empirical data our minds are able to process, but on the other hand due to their imperfection they are a boundary we will probably never cross. Human beings are sentenced therefore to life in the sensory „Panopticon” of seeing other and ourselves through the bars of social roles, cultural values and institutions. In this context the visual aspect of "doing" anthropology in the field is related to the somehow esthetic evaluation of these fields of our existence and a visual translation into our own terms, symbols and metaphors. We simply cannot leave behind what is culturally determined. Our cultural glasses are accompanying us through all stages of life and in all of our actions, shaping them through motivating agency on the basis of particular cultural ideologies.

Being aware of our ethnocentric evaluation and culturally limited worldview is certainly new to some researches, and surely not widely accepted in the public sphere in countries with $\mathrm{w}$ homogenous cultural structure (or rather a popular view of a national monolithic community), which is very much the case of Poland for example. The aim of anthropological research in this case is often to highlight the real cultural diversity of these societies, carefully hidden by recent history (in Eastern Europe the time of the communist regimes), as well contemporary or future processes which will involve these societies to confront and acknowledge the presence of the „Other”. Visualizing cultural diversity makes probably the attempts to apply anthropological knowledge a much easier task, or at least it allows to make the first move in the right direction.

Bringing together again anthropology and the field through the visual component has to include the vast discourse, which is being associated with this issue. As methodology of visual anthropology has gained much attention through works of such authors like Sarah Pink, Jay Ruby, Marcus Banks, or John Collier its theoretical foundations are still at stake. The visual discourse is in this scientific domain 
scattered with polemical debates on what anthropology is allowed to do, and what should be left as it is. Its a key issue in today's anthropology, and not just in relation to its visual sphere. Subjective engagement of the researcher when conducting fieldwork is regarded by some as a unnecessary and dangerous, thus leading to falsification of ethnographic data. Our own eyes cannot be trusted anymore. A radical disconnection is needed, a groundbreaking de-visualization of anthropology, which could save the day (scientific objectivism) - as some of those critics say. This kind of critique however does not see the close link of contemporary cultural processes with the visual basis. The presence of new media and visual technologies seem to expand the range of references of human agency in contemporary culture, especially when we speak of its global character. If the postulated de-visualization would be considered as a part of modern anthropology it might find some attention among those scholars, who are fundamentally grounded in the mentioned above critical issues. If seeing the „Other” equals believing in our anthropological knowledge it also means, that the awareness of the limitations to our scientific eyes is as much important as the effort to produce a paradigm, that does not impose any power onto the people's lives in terms of repression and dominance as it has in the past.

\section{Literatura}

Banks M., Ruby J. (2011). Made to Be Seen. Perspectives on the History of Visual Anthropology. Chicago \& London

Clifford J. (1983). Power and Dialogue in Ethnography. Marcel Griaule's Initiation. (W:) Observers Observed. Essays on Ethnographic Fieldwork. Red. G.W. Stocking, Jr. Madison \& London

Collier J. Jr., Collier M. (1986). Visual Anthropology. Photography as a Research Method. Albuquerque

Curtis E.S. (2001). The Plains Indian. Photographs of Edward S. Curtis. Lincoln

El Guindi F. (2004). Visual Anthropology. Essential Method and Theory. Oxford

Flaherty R.J. (1922). How I Filmed Nanook of the North. Adventures with the Eskimos to Get Pictures of Their Home Life and Their Battles with Nature to Get Food. The Walrus Fight. „World's Work” October, s. 632-640

Gross L. (1985). Life vs. Art: The Interpretation of Visual Narratives. „Studies in Visual Communication" vol. 11, no. 4, Fall, s. 2-11

Interart Poetics: Essays on the Interrelations of the Arts and Media. (1997). Red. U.B. Lagerroth, H. Hedling, E. Hedling. Amsterdam-Atlanta

Kennedy M.H. (2001). Introduction. (W:) E.S. Curtis, The Plains Indian. Photographs of Edward S. Curtis. Lincoln

Peacock J.L. (2004). The Anthropological Lens. Harsh Light, Soft Focus. Cambridge

Pink S. (2006), The Future of Visual Anthropology. Engaging the Senses. London and New York

Pink S. (2009). Visual Interventions. Applied Visual Anthropology. Oxford, New York

The Principles of Visual Anthropology. (2003). Red. P. Hockings. Berlin 
Ruby J. (1981). Seeing Through the Pictures: The Anthropology of Photography. „Camera Lucida” no 3, s. 19-32

Ruby J. (1989). The Teaching of Visual Anthropology. (W:) Teaching of Visual Anthropology. Red. P. Chiozzi. Firenze

Ruoff J. (1998). An Ethnographic Surrealist Film: Luis Buñuel's „Land Without Bread”. „Visual Anthropology Review" vol. 14, no. 1 (Spring/Summer), s. 45-57

Stocking G.W. Jr. (1987). Victorian Anthropology. New York

Worth S., Adair J. (1972). Through Navajo Eyes. An Exploration in Film and Anthropology. Bloomington-London

\section{Zobaczyć znaczy uwierzyć. Antropologiczne spojrzenia na kulturę}

\section{Streszczenie}

Wizualny aspekt kultury, rozumianej w jej najszerszym z możliwych sensów, od dawna jest przedmiotem dociekań naukowych. Uwaga ta odnosi się do szczególnego wymiaru badań nad wizualnością, realizowanych w ramach paradygmatu antropologicznego. Jakkolwiek jego granice są dziś płynne i cechuje je swobodne przenikanie się określonych tradycji badawczych, to możemy z dużą dozą pewności wskazać na wyraźny historyczny ciąg myśli o charakterze antropologicznym, który odnosi się bezpośrednio do kulturowych kontekstów otaczających sferę zmysłową. W szczególności uwaga zostaje skupiona na relacjach łączących obszar szeroko rozumianej wizualności i kultury. W przypadku antropologii jest to fakt znaczący, zwłaszcza że dyscyplina ta od dawna zajmuje się problemem miejsca obrazu oraz samego aktu spojrzenia w przestrzeni kulturowej. Spojrzenie stanowi swoisty akt mowy, podczas której artykułowane są partykularne kody kulturowe. W optyce antropologicznej kluczowe wydają się jednak te, które określają „Innego” w terminach odmienności kulturowej, językowej czy też niekiedy wręcz biologicznej (rasowej). Specyfika wiedzy etnograficznej opiera się zatem często na zapośredniczonym poprzez zmysł wzroku poznaniu tego, co obce, dzikie i nieprzeniknione. Kolejnym logicznym krokiem jest zatem ujarzmienie „Innego” w kategoriach naszej własnej kultury, a narzędziem tego rodzaju hegemonii staje się sfera zmysłowa.

Od czasów greckich i pism Herodota wizualne przedstawienia odmienności kulturowej zyskiwały na znaczeniu. Jest to fakt tym istotniejszy, iż w czasach antyku obraz związany był silnie $\mathrm{z}$ obiektem na nim przedstawianym. Relacje pomiędzy wizualnym obiektem a patrzącym miały charakter magiczny, w którym to patrzący włada niepodzielnie nad pokonanym w bitwie wrogiem, demonem lub dzikim zwierzęciem. Historyczne zmiany, jakie dokonały się $\mathrm{w}$ świecie zachodnim, pociągnęly za sobą także transformację miejsca obrazu w kulturze. Dyskursy religijne wieków średnich umocniły przekonanie, iż obraz łączy z rzeczywistością fizykalną niewidzialna nić, której siła tkwi nie w porządku ludzkim, lecz nadprzyrodzonym. Ikoniczny charakter wizji potępienia i zbawienia, prezentowany wiernym poprzez sztukę chrześcijańską, trwale zakorzenił się w zbiorowej świadomości mieszkańców Starego Świata i utrwalił jednocześnie antropologiczne dociekania w manierze etnocentrycznego przeświadczenia o wyższości europejskiej kultury nad tym, co leży poza granicami Europy. Początkowo antropologia współuczestniczyła w kształtowaniu się zachodniego schematu myślenia o wizualności na zasadzie dostarczania uprawomocnienia moralnej oceny różnic 
kulturowych. Wpisywała się tym samym w dyskurs kolonialny, typowy dla kontekstu rodzenia się nowoczesności w dobie militarnej, politycznej i technologicznej przewagi Zachodu. Pozaeuropejska sztuka „prymitywna”, wystawiana w galeriach i muzeach Londynu lub Paryża, stanowić miała egzemplifikację dawno utraconej niewinności i stanu „szlachetnej dzikości”. Narzędziem eksponowania obrazu „szlachetnego dzikiego” stała się nierzadko instrumentalnie traktowana egzotyka. Naturalizowanie kategorii różnicy kulturowej w tym względzie znalazło swój najbardziej skrajny wyraz między innymi w muzealniczej koncepcji „ludzkiego zoo", popularnej pod koniec XIX wieku formy przedstawiania zróżnicowania etnicznego świata $\mathrm{w}$ postaci stereotypowych wizualizacji egzotycznych plemion i ludów prezentowanych $\mathrm{w}$ ich „naturalnym” środowisku.

W podobny sposób wizualność poddawano uprzedmiotowieniu w Stanach Zjednoczonych, zmagających się w tym samym czasie $\mathrm{z}$ problemem oporu asymilacyjnego tubylczych Amerykanów. Obrazy północnoamerykańskich Indian prerii, przedstawione na serii fotografii autorstwa Edwarda Sheriffa Curtisa, zyskały status ikonicznych odniesień tak dla wielu Amerykanów, jak i ludzi zafascynowanych wysublimowaną estetyką kultur indiańskich. Manipulacja obrazem, charakterystyczna dla warsztatu Curtisa, nie przesłaniała jednak potrzeby czerpania z jego zdjęć wiedzy etnograficznej dla osób jedynie fragmentarycznie obeznanych z dyskursem wczesnej antropologii.

Nie tylko fotografia odegrała znaczącą rolę w procesie kształtowania się dyskursu antropologicznego, a później także wyłonienia się antropologii wizualnej. Ważnym elementem obrazowania rzeczywistości stała się także kinematografia. Filmy o charakterze protoetnograficznym, takie jak „Nanuk z Północy” Roberta J. Flaherty’ego i „Kraj bez chleba” Louisa Buñuela ukonstytuowały dyskurs antropologiczny w szerokim kontekście kultury popularnej początku $\mathrm{XX}$ wieku. Ich bezsporny wpływ na masową wyobraźnię widzów oraz przystępny język walnie przyczyniły się do zakorzenienia przekonania o dostarczaniu przez tego typu obrazy etnograficznej prawdy. Zafałszowania rzeczywistości dokonane przez Flaherty’ego i Buñuela w ich filmach były w tym świetle jedynie nieistotnym brakiem naukowej wiarygodności, która dla przeciętnego widza była zbędna.

Antropologia wizualna stała się z biegiem czasu swoistą odpowiedzią na konieczność ukazania rzeczywistości kulturowej taką, jaka jawi się nie tylko zachodnim twórcom filmowym czy fotografom, lecz również ludziom przedstawianym na tych obrazach. Zwrot w stronę tak zwanego "tubylczego punktu widzenia" powoli zyskiwał na popularności w antropologii i innych naukach społecznych w ramach kierunków interpretacyjnych i tekstualnych. Tym jednak, co charakteryzuje współczesną antropologię wizualną, jest położenie nacisku na ukazanie związku sfery wizualnej z budowaniem uwarunkowanej kulturowo sfery światopoglądowej opartej na określonych procesach poznawczych. Te zaś są nadal bezpośrednio związane z operowaniem obrazem jako elementem łączącym świadomość z poznawaną rzeczywistością. 